dr inz. Zygmunt Marciniak,

dr Wtodzimierz Stawecki

Instytut Pojazdów Szynowych ,TABOR”

dr inz. Ireneusz Pielecha

dr inż. Jacek Pielecha

Politechnika Poznańska

\title{
Problemy emisji spalin ze specjalnych pojazdów szynowych
}

\begin{abstract}
W artykule przedstawiono analizę ekologicznq specjalnych pojazdów szynowych na przykladzie ciagnika szynowo-drogowego. Przedstawiono wyniki pomiarów emisji sktadników gazowych oraz czastek stalych w rzeczywistych warunkach ruchu tego pojazdu. Zaproponowano możliwości zastapienia lokomotyw manewrowych przez pojazdy szynowo-drogowe.
\end{abstract}

\section{Wstęp}

Zagadnienia ekologiczne dotyczące ograniczania zużycia energii, paliw i emisji związków szkodliwych znajdują swoje odzwierciedlenie również w obszarach związanych z pojazdami szynowymi. Niniejszy artykuł dotyczy zagadnienia wykorzystania ciagników szynowo-drogowych $\mathrm{w}$ aspekcie ograniczenia emisji składników szkodliwych i potencjalnych możliwości zastapienia nimi spalinowych lokomotyw manewrowych.

Pojazdy specjalne trakcji szynowej często bazują na konstrukcjach samochodów ciężarowych (np. Iveco, Star - do prowadzenia prac pociaggowych i manewrowych na bocznicach kolejowych), ale również ciągników (Ursus, Crystal).

Ciagnik szynowo-drogowy to ciagnik przeznaczony do prac związanych z przetaczaniem wagonów po torach (wąskich i szerokich). Wyposażenie tego ciągnika oparte jest na kompletacji modelu Crystal z dodatkowym reduktorem biegów pełzających oraz zwężonym rozstawie kół. Model szynowy jest doposażony przez Instytut Pojazdów Szynowych TABOR w układ umożliwiający jazdę po torach kolejowych i podłączenie $\mathrm{z}$ wagonem kolejowym. Ciaggnik ten wykonuje prace zarówno jako lokomotywa, jak również ciagnik do holowania po drodze.

Cechy konstrukcyjne tych pojazdów umożliwiają:

- wjazd na tory na dowolnym przejeździe kolejowym,

- łatwe wstawianie pojazdu na tor,

- prosty zjazd z toru na drogę,

- eksploatację na torach o różnej szerokości (1524 i $1435 \mathrm{~mm}$ ),

- łatwe przestawianie z toru normalnego na szeroki,

- dojazd drogami terenowymi do miejsca przeznaczenia.

\section{Metodyka badawcza}

Badania emisji składników szkodliwych w spalinach prowadzono $\mathrm{z}$ wykorzystaniem ciagnika szynowodrogowego Crystal Orion C13. Widok ciagnika wyposażonego $\mathrm{W}$ aparaturę pomiarową przedstawiono na rys. 1. Parametry techniczne silnika przedstawiono w tabeli 1.
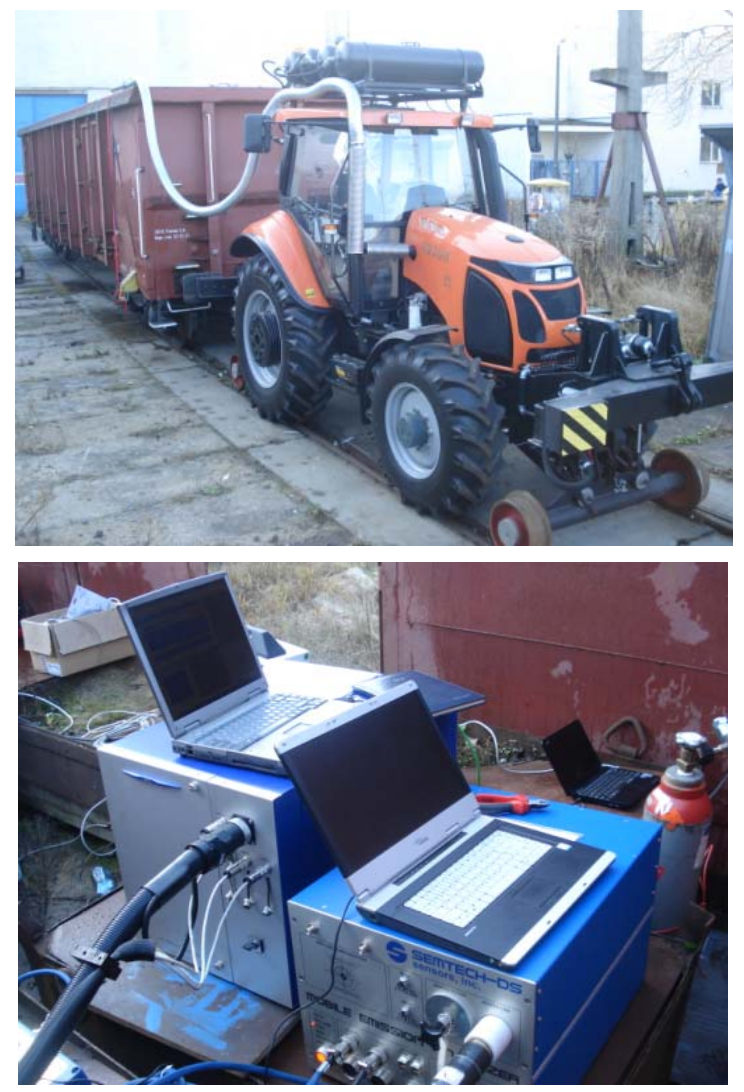

Rys. 1. Badania ciagnika Crystal z zamontowanymi układami pomiaru emisji spalin wykonane w IPS Tabor w Poznaniu 
Parametry techniczne silnika spalinowego ciągnika szynowo-drogowego [4]

T a b e l a 1

\begin{tabular}{|c|l|c|c|}
\hline Lp. & Wielkość & Jednostka & Wartość \\
\hline 1. & $\begin{array}{l}\text { Typ/seria } \\
\text { pojazdu }\end{array}$ & - & $\begin{array}{c}\text { Ciagnik szynowo-kołowy } \\
\text { Orion Crystal 13 }\end{array}$ \\
\hline 2. & Typ silnika & - & Martin Z.8701.12 \\
\hline 3. & $\mathrm{~N}_{\mathrm{e}}$ & $\mathrm{kW}$ & 98 \\
\hline 4. & $\begin{array}{l}\text { Układ cylin- } \\
\text { drów }\end{array}$ & & $4 / \mathrm{R}$ \\
\hline 5. & $\mathrm{n}_{\text {Ne-max }}$ & $\mathrm{obr} / \mathrm{min}$ & 2200 \\
\hline 6. & $\mathrm{~V}_{\mathrm{ss}}$ & $\mathrm{dm}^{3}$ & 6,842 \\
\hline 7. & $\mathrm{~g}_{\mathrm{e}}$ & $\mathrm{g} /(\mathrm{kW} \cdot \mathrm{h})$ & 240 \\
\hline
\end{tabular}

Do pomiarów związków toksycznych wykorzystano mobilne analizatory spalin wykorzystywane do badań drogowych $[5,6]$ :

- pomiar stężenia związków szkodliwych $(\mathrm{CO}, \mathrm{HC}$, $\mathrm{NO}_{\mathrm{x}}, \mathrm{CO}_{2}$ ) oraz masowe natężenie przepływu spalin - SEMTECH DS firmy SENSORS [8],

- pomiar liczby cząstek stałych - mobilny analizator Particle Counter firmy AVL [9],

- pomiar wielkości i masy cząstek stałych - mobilny analizator 3090 EEPS (Engine Exhaust Particle Si$z r^{\mathrm{TM}}$ Spectrometer) firmy TSI Incorporated [10].

Charakterystykę emisji składników gazowych i emisji cząstek stałych przeprowadzono przy uwzględnieniu liczby cząstek stałych oraz ich rozkładu wymiarowego. Pomiary liczby cząstek stałych miały na celu określenie liczby cząstek emitowanych w danym punkcie pracy silnika. Pomiarów dokonano bez obciążenia dla zimnego i ciepłego rozruchu silnika oraz dla stałych prędkości obrotowych silnika 600,1000, 1500 oraz $2000 \mathrm{obr} / \mathrm{min}$. W dalszej części artykułu przedstawiono wyniki badań emisji składników gazowych i cząstek stałych w punktach odpowiadających testowi ISO 8178 cykl F, który jest stosowany podczas badań pojazdów szynowych. Określono rozkład wymiarowy cząstek stałych dla powyższych punktów pracy silnika. Rezultaty przedstawiono w postaci charakterystyki widmowej emisji rozkładu wymiarowego cząstek stałych oraz wielkości uśrednionych (w czasie pomiaru) poszczególnych rozkładów wielkości cząstek: pola powierzchni oraz masy. Masę cząstek stałych obliczano, przyjmując że gęstość cząstek stałych jest niezależna od ich średnicy charakterystycznej (aerodynamicznej) i wynosi $1 \mathrm{~g} / \mathrm{cm}^{3}$.

\section{Badania emisji spalin podczas rozruchu i biegu luzem silnika ciągnika}

Zimny rozruch silnika spalinowego o zapłonie samoczynnym jest główną przyczyną wysokiej emisji składników toksycznych spalin (rys. 2). Emisja godzinowa tlenku węgla jest o $50 \%$ wyższa w przypadku zimnego rozruchu silnika w stosunku do silnika nagrza nego. Wyższa jest również emisja węglowodorów (o $30 \%$ ). Emisja tlenków azotu wzrasta o $100 \%$, co jest związane z większą dawką rozruchową. Zużycie paliwa, które jest odpowiednikiem emisji dwutlenku węgla w czasie zimnego rozruchu wzrasta o $40 \%$. Podczas zwiększania prędkości obrotowej silnika (bez obciążenia) wzrasta emisja wszystkich składników szkodliwych.

Całkiem nowym zagadnieniem dotychczas niepublikowanym w Polsce jest emisja cząstek stałych w rzeczywistych warunkach ich ruchu pojazdów szynowych.

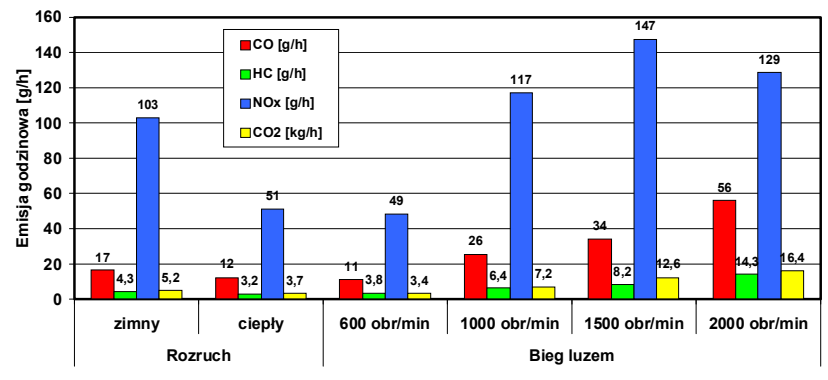

Rys. 2. Emisja godzinowa składników gazowych i zużycie paliwa podczas rozruchu i biegu luzem silnika ciągnika szynowodrogowego

W dalszej części przedstawiono wyniki z badań emisji cząstek stałych podczas zimnego i ciepłego rozruchu silnika. Wynika z niego, że emisja cząstek stałych podczas zimnego rozruchu jest o $25 \%$ większa niż przy rozruchu ciepłym (rys. 3). Wzrost wydatku spalin przy wyższych prędkościach obrotowych powoduje, że wraz z nim wzrasta emisja cząstek stałych. Liczba cząstek stałych wzrasta szybciej niż emisja masowa PM, co ma związek z większą liczbą małych cząstek podczas większej prędkości obrotowej silnika.

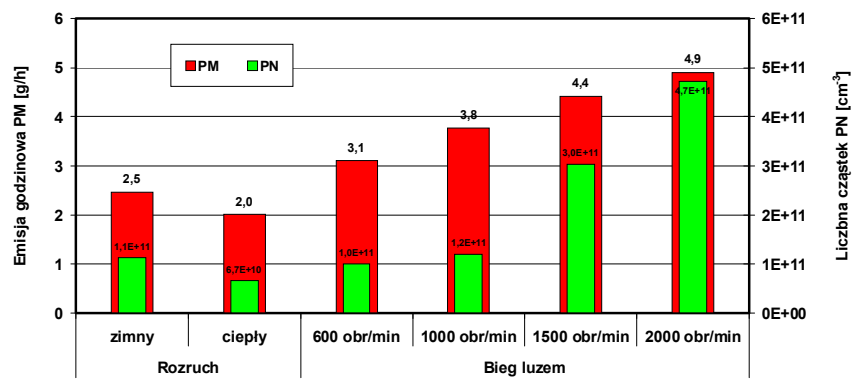

Rys. 3. Średnie wartości masy i liczby cząstek stałych emitowanych podczas rozruchu i biegu luzem silnika

Biorąc pod uwagę rozkłady cząstek stałych, należy zauważyć, że zmiana warunków pracy silnika (od rozruchu poprzez wzrost prędkości obrotowych) nie prowadzi do zmiany rozkładu wymiarowego cząstek stałych (rys. 4). Największa liczbą cząstek stałych przy

pada na zakres około $10 \mathrm{~nm}$ i wynosi około 30000 $\mathrm{cm}^{-3}$. Wpływ zmiany prędkości obrotowej jest zauważalny dopiero przy $\mathrm{n}=1000 \mathrm{obr} / \mathrm{min}$ : znaczenia zaczyna nabierać liczba cząstek o średnicy 50-100 nm. Wpływ warunków pracy silnika na rozkład po- 
wierzchniowy cząstek stałych jest klasyczny, czyli ze wzrostem średnicy cząstek wzrasta ich powierzchnia osiagając maksimum dla cząstek powyżej $500 \mathrm{~nm}$. Jednakże należy zauważyć, że ze wzrostem obciążenia zaczyna wzrastać powierzchnia cząstek o średnicach około $100 \mathrm{~nm}$. Tak wyraźnej zależności nie odnotowano dla liczby cząstek w tym przedziale wymiarowym. Nie odnotowano różnic między rozkładem powierzchniowym PM podczas rozruchu i ustalonego biegu jałowego $(n=600 \mathrm{obr} / \mathrm{min})$. W pozostałych przypadkach wzrost prędkości obrotowej i obciążenia powoduje wzrost powierzchni cząstek stałych o około $100 \%$ przy ustalonej średnicy w zakresie $100 \mathrm{~nm}$. Przy większych średnicach cząstek stałych zmiany nie występują. Znacznie mniejsze zmiany występują $\mathrm{w}$ rozkładach objętościowych i masowych PM w różnych warunkach pracy silnika. Zauważalne zmiany (rzędu kilku procent) dotyczą jedynie średnic cząstek stałych o wartościach $100 \mathrm{~nm}$. W pozostałych przedziałach nie odnotowano zmian rozkładów przy zmiennych warunkach pracy silnika ciagnika szynowo-drogowego.
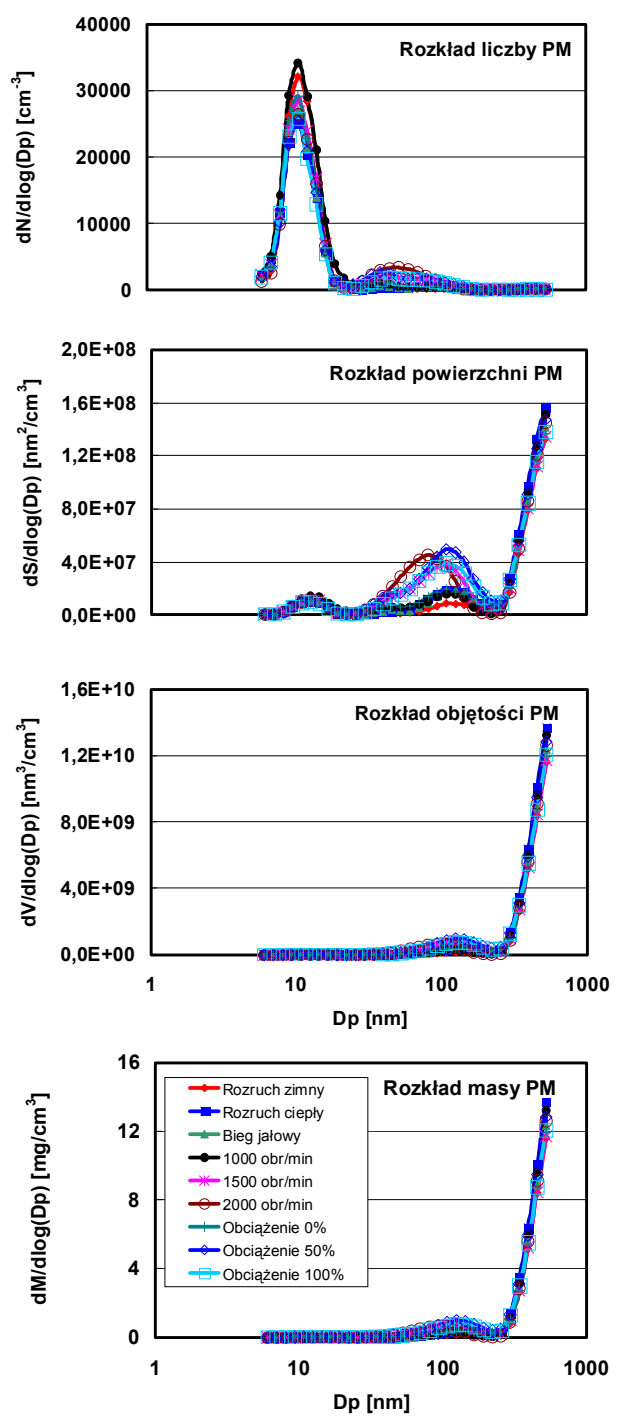

Rys. 4. Rozkłady wielkości cząstek stałych: liczbowy, powierzchniowy, objętościowy oraz masowy

\section{Badania emisji spalin zgodnie $z$ testem ISO 8178- F}

Uwzględniając powyższe wyniki badań w zakresie emisji składników szkodliwych spalin wyznaczono wskaźniki ekologiczne ciagnika szynowo-drogowego. Wykorzystano do tego celu badania podczas prób torowych, określając wartości emisji spalin w punktach testu ISO 8178-F. Pomimo, że silnik nie ma zastosowania jako źródło napędu typowych pojazdów szynowych badania właśnie według tego testu, a wartości emisji odniesiono do limitów UIC 624. Dane techniczne badanego silnika zawierają informacje o spełnieniu przez niego normy Euro IIIA oraz Tier 3 [3]. Ze względu na spełnianie normy Euro IIIA jej limity również zamieszczono na wykresie (rys. 5). Należy jednak zauważyć, że limit ten dotyczy badań wykonanych w teście ISO 8178-C1. Cykl C1 dotyczy testu 8-fazowego, a nie jak wspomniano wyżej cyklu F (test 3-fazowy). Z tego względu na wykresie przekroczone są limity tej normy (pomimo spełnienia jej przez silnik). Zamieszczenie tych limitów jest o tyle ważne, że silnik posiada niewielką wartość emisji składników szkodliwych i obecne normy UIC spełniane są dla wszystkich składników toksycznych w teście ISO 8178-F. Przeprowadzone badania wskazują na możliwości znacznych oszczędności w zużyciu paliwa podczas pracy manewrowej tego typu pojazdów w porównaniu do spalinowych lokomotyw manewrowych. Zużycie paliwa na biegu jałowym wynosi 4,1 $\mathrm{dm}^{3} / 100 \mathrm{~km}$ (przeliczeniowe), przy 50-procentowym obciążeniu wartość ta wynosi $15,3 \mathrm{dm}^{3} / 100 \mathrm{~km}$ oraz $31,2 \mathrm{dm}^{3} / 100 \mathrm{~km}$ przy pełnym obciążeniu.

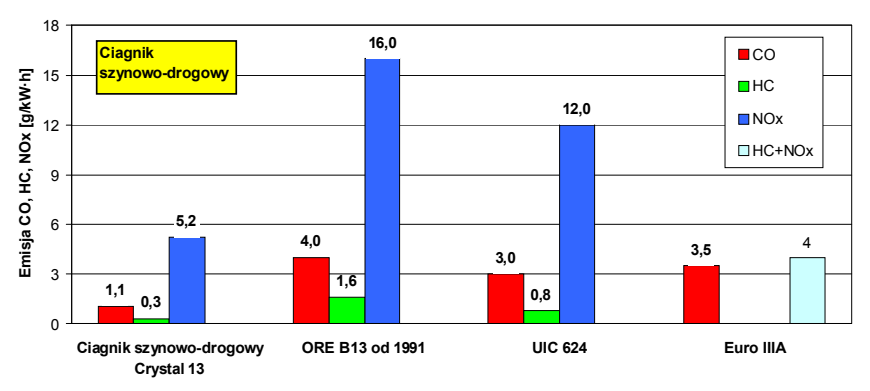

Rys. 5. Wartości emisji składników toksycznych ciagnnika szynowo-drogowego na tle norm emisji spalin

Wyznaczone wartości emisji spalin pozwoliły na oszacowanie możliwości zastapienia spalinowych lokomotyw manewrowych ciagnikami szynowodrogowymi. Poniższa analiza przedstawia możliwość zastapienia lokomotyw manewrowych na przykładzie lokomotywy SM42 specjalnymi pojazdami szynowymi (w tym przypadku ciagnikiem szynowodrogowym). Zalety specjalnych pojazdów szynowodrogowych $\mathrm{w}$ porównaniu z lokomotywami manewrowymi to: 
- trzykrotnie niższa cena zakupu ciagnika szynowodrogowego w stosunku do ceny najtańszej lokomotywy manewrowej,

- sześciokrotnie niższe koszty eksploatacji ciągnika,

- trzykrotnie wyższe właściwości trakcyjne,

- możliwość prowadzenia pojazdów bez uprawnień kolejowych na bocznicach własnych,

- możliwość zmechanizowania prac porządkowych infrastruktury kolejowej lub tramwajowej,

- możliwość adaptacji używanych pojazdów drogowych na pojazdy szynowo-drogowe.

Ciagnik szynowo-drogowy Orion C13 produkowany przez spółkę Crystal Traktor z Sieradza, spełnia następujace wymagania [1]:

- dopuszczalna ilość wagonów holowanych z przodu na torze poziomym: 6 (z hamulcami pneumatycznymi) oraz 3 (bez hamulców),

- dopuszczalna ilość wagonów holowanych z tyłu na torze poziomym: 9-10 (z hamulcami pneumatycznymi) oraz 4-5 (bez hamulców),

- dopuszczalna prędkość jazdy po torze prostym z wagonami: $10 \mathrm{~km} / \mathrm{h}$ (z hamulcami pneumatyczny$\mathrm{mi}$ ) oraz $5 \mathrm{~km} / \mathrm{h}$ (bez hamulców),

- dopuszczalna prędkość jazdy po łukach i rozjazdach: $5 \mathrm{~km} / \mathrm{h}$,

- maksymalna prędkość na torze: $20 \mathrm{~km} / \mathrm{h}$.

Wartości emisji składników szkodliwych wraz z emisją cząstek stałych ciągnika szynowo-drogowego zestawiono $\mathrm{z}$ badaniami lokomotywy manewrowej SM42 $[2,7]$ (rys. 6). Symulacje przeprowadzono przy założeniu, że ciągnik szynowo-drogowy ma pięciokrotnie zwiększone czasy przetoków (zmniejszenie dopuszczalnej liczby ciagniętych wagonów wymusza pięciokrotny wzrost czasu pracy ciagnika).

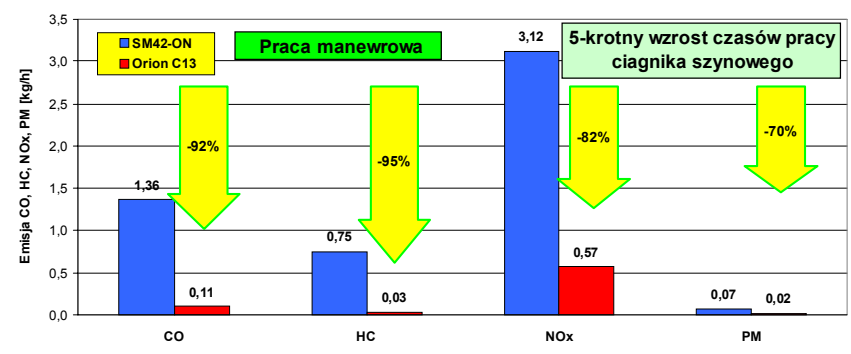

Rys. 6. Zestawienie emisyjności lokomotywy SM42 i ciąnika szynowo-drogowego w warunkach pracy manewrowej
Analiza pracy lokomotywy i ciagnika szynowodrogowego wykazuje znaczne oszczędności emisji spalin do atmosfery wszystkich składników szkodliwych. Minimalne zmniejszenie emisji składników szkodliwych to wartość około $70 \%$ (dotyczy cząstek stałych; pozostałe składniki szkodliwe ograniczane są w większym stopniu). Oznacza to, że pomimo wydłużenia czasu pracy ciągnika szynowego możliwe jest zaoszczędzenie podczas 2 godzin pracy lokomotyw SM42: ponad $2 \mathrm{~kg} \mathrm{CO}, \quad 1,5 \mathrm{~kg}$ węglowodorów oraz $5 \mathrm{~kg}$ tlenków azotu oraz $100 \mathrm{~g}$ cząstek stałych. Dla porównania emisja godzinowa cząstek stałych z pojazdu samochodowego (w teście jezdnym) wynosi około $2 \mathrm{~g} / \mathrm{h}$.

Największe zyski ekologiczne dotyczą emisji węglowodorów - 25-krotne zmiany na korzyść pojazdów specjalnych (ciagnika szynowego). Emisja tlenku węgla może zostać ograniczona 12-krotnie. Na uwage zasługuje fakt ponad 3-krotnego obniżenia emisji cząstek stałych. Zmiany te uwzględniają wydłużony czas pracy specjalnego pojazdu szynowego (5-krotny wzrost czasu powoduje przedstawione korzyści skrócenie tego czasu będzie skutkowało wzrostem stopnia ekologiczności tych zmian, który będzie rozumiany jako krotność zysku ekologicznego).

\section{Wnioski}

1. Zmiana prędkości obrotowej silnika na biegu luzem (bez obciążenia) znacząco wpływa na zmianę stężenia składników gazowych spalin. Emisja cząstek stałych wzrasta o $25 \%$ podczas zimnego rozruchu (w porównaniu do rozruchu ciepłego silnika).

2. Analiza liczby cząstek stałych w zakresie zmian prędkości obrotowej silnika na biegu luzem silnika wskazuje na występowanie maksymalnej liczby cząstek o wymiarach około $10 \mathrm{~nm}$ dla każdej badanej prędkości obrotowej.

3. Charakterystyki rozkładu wymiarowego liczby cząstek stałych wykazują istnienie maksimum liczby cząstek o średnicy w zakresie $100 \mathrm{~nm}$, jednak maksymalne wartości powierzchni, objętości i masy dotyczą cząstek stałych o średnicy ponad 500 $\mathrm{nm}$.

4. Zastapienie spalinowych lokomotyw manewrowych ciagnikami szynowo-drogowymi pozwoliłoby na 3krotne obniżenie emisji PM, 12-krotne zmniejszenie emisji HC oraz 25-krotne obniżenie emisji tlenku węgla.

\section{Literatura}

[1] Brodowski Z., Traktorem po torach, Czasopismo Projektowanie i Konstrukcje Inżynierskie, Wydawnictwo ITER, 7/8(10/11), 2008.

[2] Marciniak Z., P i e le ch a I., Próby i badania silników spalinowych lokomotyw $i$ lekkich pojazdów szynowych $w$ aspekcie poprawy ich parametrów eksploatacyjnych, XVIII Konferencja Naukowa „Pojazdy Szynowe”, Katowice-Ustroń 2008.

[3] Materiaty firmowe AGCO SISU Power, 3rd Generation Series 4-Cylinder Diesel Engine, agcosisupowercom-bin.directo.fi.

[4] Materiaty firmy Crystal Traktor sp. z o.o., www.traktor.pl. 
[5] Merkisz J., Pielecha J., Gis W., Gaseous and Particle Emissions Results from Light Duty Vehicle with Diesel Particle Filter, SAE Technical Paper 2009-01-2630 .

[6] Merkisz J., Pi e le ch a J., Analysis of Particle Concentrations and Smoke in Common-Rail Diesel Engine, SAE Technical Paper 2008-01-1743.

[7] P i e le ch a I., C z erwińs ki J., Sprawozdanie z badania emisji składników toksycznych spalin silnika lokomotywy spalinowej SM42 nr 2508, Opracowanie SB-2277, Praca IPS ,,Tabor”, Poznań 2006.

[8] Shahinian V.D., SENSORS tech-ct Update Application Software for SEMTECH Mobile Emission Analyzers, Sensors 4th Annual SUN (SEMTECH User Network) Conference, Anna Arbor 2007.

[9] www.avl.com: AVL Particle Counter.

[10] www.tsi.com: TSI Incorporated, Engine Exhaust Particle Sizer - 3090. 